Tohoku J. exp. Med., 1970, 100, 1-13

\title{
Autoradiographic Studies on Heart Muscle Cells in Normal Rats
}

\author{
Rikuro Sasaki, Toshiaki Morishita and Shoichi Yamagata \\ Department of Internal Medicine (Prof. S. Yamagata), \\ Tohoku University School of Medicine, Sendai
}

\begin{abstract}
Autoradiographic studies on the synthesis of DNA in heart muscle cells of younger normal rats after administration of ${ }^{3} \mathrm{H}$-thymidine were made. The labeling index of heart muscle cells in 4 hours was $8.3 \%$ on the 2 nd day of life and it gradually declined to $0.15 \%$ in 3 weeks. The labeling index of interstitial cells was $9.8 \%$ on the second day of life and it similarly declined to $1.0 \%$ in 3 weeks. These results are to be added as furthr evidence to cell division of heart muscle with postnatal growth of the heart.
\end{abstract}

The concept of cell division of heart muscle cell as well as interstitial cell of normal rats with postnatal growth has been presented on the bases of histometrical studies, chemical determinations of DNA content in the heart muscle, and presence of mitosis by colchicine treatment. ${ }^{1-3}$ The use of ${ }^{3} \mathrm{H}$-thymidine, on the other hand, has been applied to elucidate DNA synthesis in nuclei of many organs. Though various attempts have been made to investigate the relation between cell division and the number of cells incorporating ${ }^{3} \mathrm{H}$-thymidine into DNA, the observations on heart muscle are scarce.

The purpose of this paper is to add further evidence for the cell division of the heart muscle of normal rats through the autoradiographic studies on the synthesis of DNA after administration of ${ }^{3} \mathrm{H}$-thymidine.

\section{Materials and Methods}

Eight new-born rats of Wistar strain of the same venter were used. ${ }^{3}$ H-thymidine was given intraperitoneally ( $1 \mu \mathrm{c} / \mathrm{g}$ of body weight) on the 2 nd day, and 1,2 and 3 weeks after birth. Rats were killed by decapitation 4 hours after the administration. Then, the hearts were fixed in $10 \%$ formalin solution. Histological specimens were made as usual. For autoradiographic technique, Konidol (Sakura $\mathbf{N R}-\mathbf{M}_{2}$ ) was used as an emulsion, and dipping method was applied. Exposure period was 3 weeks. Development was made by use of Konidol X (Sakura). Then, the histological specimens were stained with hematoxylin and eosin, and the labeling index of heart muscle cell as well as interstitial cell was estimated in each group.

\section{RESULTS}

The incorporation of ${ }^{3} \mathrm{H}$-thymidine into nuclei of heart muscle cells was shown

Received for publication, September 2, 1969. 
R. Sasaki et al.

TABLE 1. Labeling indices of cells

\begin{tabular}{|c|c|c|}
\hline Age & $\begin{array}{c}\text { Heart muscle cell } \\
\%\end{array}$ & $\begin{array}{c}\text { Interstitial cell } \\
\%\end{array}$ \\
\hline 2 days & 8.8 & 10.4 \\
\hline 211 & 7.8 & 9.2 \\
\hline 1 week & 5.6 & 7.2 \\
\hline 11 & 2.8 & 3.8 \\
\hline 2 weeks & 1.6 & 3.0 \\
\hline 2 & 0.6 & 3.6 \\
\hline 311 & 0.2 & 0.8 \\
\hline$\because "$ & 0.1 & 1.2 \\
\hline
\end{tabular}

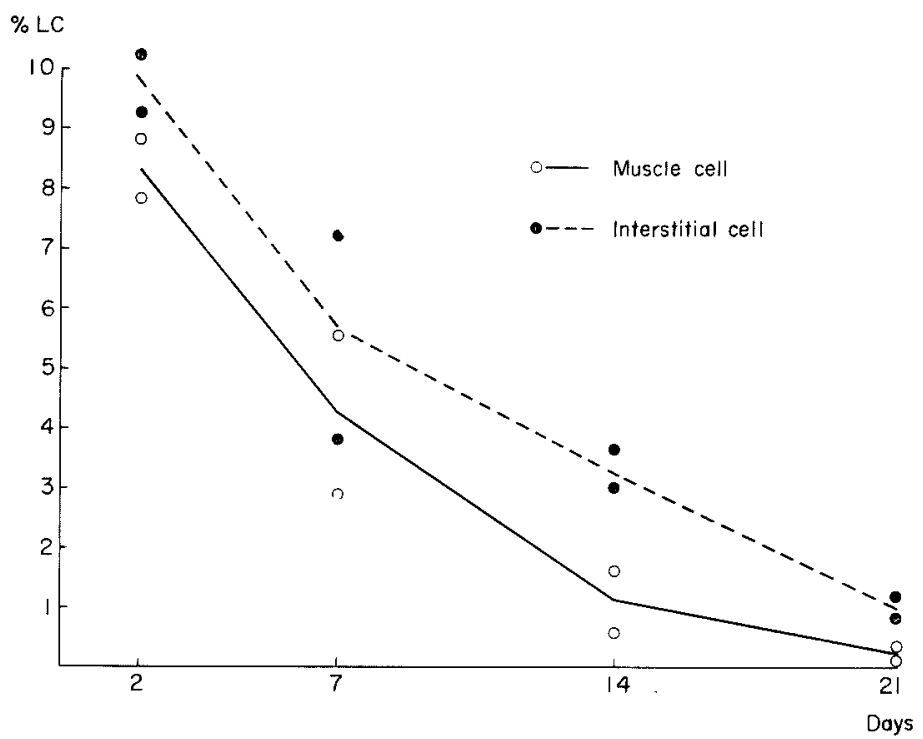

Fig. 10. Labeling indices and age.

TABLe 2. Grain counts in 2-day-old rats

Grain count

10
15
20
25
30
35
40
45

Mean count
Number of muscle cell nucleus

4
10
16
11
3
2
2
2

50
22
$\left(\begin{array}{c} \\ (\pi .2\end{array}\right)$

Number of interstitial cell nucleus 
in Figs. 1-7. Figs. 8 and 9 show the synthesis of DNA in nuclei of interstitial cells. In each figure, (A) was focussed on nucleus itself and (B) on grains incorporated into the same nucleus. Figs. 2, 4, 7 and 8 show mitosis with concomitunt uptake of ${ }^{3} \mathrm{H}$-thymidine. In this study, nuclei with more than 10 grains are considered to be "labeled" ones.

The uptake of ${ }^{3} \mathrm{H}$-thymidine into nuclei of muscle cells and interstitial cells in very young rats is abundant but becomes scarce within 3 weeks. The labeling index of heart muscle cell was $7.8-8.8 \%$ (av. $8.3 \%$ ) on the 2 nd day after birth, $2.8-$ $5.6 \%$ (av. $4.2 \%$ ) on the 7 th day, $0.6-1.6 \%$ (av. $1.1 \%$ ) on the 14 th day, and $0.1-$ $0.2 \%$ (av. $0.15 \%$ ) on the 21 st day. The labeling index of interstitial cell was $9.2-$ $10.4 \%$ (av. $9.8 \%$ ) on the 2 nd day, $3.8-7.2 \%$ (av. $5.5 \%$ ) on the 7 th day, $3.0-3.6 \%$ (av. $3.3 \%$ ) on the 14 th day, and $0.8-1.2 \%$ (av. $1.0 \%$ ) on the 21 st day (Table 1 and Fig. 10). Grain counts on the 2 nd day ranged from 10 to 45 in muscle cell nuclei and 10 to 30 in intərstitial cell nuclei (Table 2 ).

\section{Discussion}

Undoubtedly ${ }^{3} \mathrm{H}$-thymidine is incorporated into nuclei of heart muscle cells and of interstitial cells in young rats. Rumyantsev ${ }^{4}$ has made quite a similar observation in autoradiographic studies on DNA synthesis of heart muscle of rats during embryonal and postnatal growth. He has stated that there are labeled nulcei of heart muscle until the 17 th postnatal day. He has also reported that practically no muscle cell nuclei incorporating ${ }^{3} \mathrm{H}$-thymidine are found in the normal myocardium of adult mice and frogs. ${ }^{5}$ In this study, labeled nuclei of heart muscle cells and mitosis of heart muscle cells with concomitant uptake of ${ }^{3} \mathrm{H}$-thymidine were found even on the 21st day after birth.

The problem is whether all these incorporated cell nuclei lead to mitosis or not. Pelc $^{6}$ has mentioned that non-mitotic incorporation of ${ }^{3} \mathrm{H}$-thymidine into DNA may occur in so-called non-dividing tissues of adult animals. Sandritter and his associates ${ }^{7,8}$ have reported evidence of polyploidisation of a large number of muscle nuclei in the hypertrophic human hearts in cytophotometric measurements. Our results of determination of DNA contents of heart muscle cells, however, do not agree with those obtained by previous investigators and show that the DNA content is same in each nucleus, regardless of difference of the kind of cells and heart weight. ${ }^{2,9}$ Then, it seems to be more probable that all labeled cell nuclei lead to mitosis.

Furthermore, a new method was devised ${ }^{10}$ to determine DNA synthetic time and mitotic time from these autoradiographic technique. The DNA synthetic time and mitotic time were quite compatible with those estimated from cell count ${ }^{1}$ and mitosis. ${ }^{3}$ It is believed that the incorporation of ${ }^{3} \mathrm{H}$-thymidine into cell nuclei is preparing for mitosis.

\section{References}

1) Sasaki, R., Watanabe, Y., Morishita, T. \& Yamagata. S. Estimation of the cell number 
of heart muscles in normal rats. Tohoku J. exp. Med., 1968, 95, 177-184.

2) Sasaki, R., Watanabe, Y., Morishita, T. \& Yamagata, S. Determination of deoxyribonucleic acid content of heart muscle and myocardial growth in normal rats. Tohoku J. exp. Med., 1968, 95, 185-192.

3) Sasaki, R., Morishita, T. \& Yamagata, S. Mitosis of heart muscle cells in normal rats. Tohoku J. exp. Med., 1968, 96, 405-411.

4) Rumyantsev, P.P. DNA synthesis and nuclear division in embryonal and postnatal histogenesis of myocardium (autographic study). Arkh. Anat. Gistol. Embriol., 1964, 47, 59 (in Russian) in Fed. Proc., 1965, 24 (Trans. suppl.), T899-T902.

5) Rumyantsev, P.P. Autoradiographic study on the synthesis of DNA, RNA, and proteins in normal cardiac muscle cells and those changed by experimental injury. Folia Histochem. Cytochem., 1966, 4, 397-424.

6) Pelc, S.R. Labelling of DNA and cell division in so-called non-dividing tissues. $J$. Cell Biol., 1964, 22, 21-28.

7) Sandritter, W. \& Scomazzoni, G. Deoxyribonucleic acid content (Feulgen photometry) and dry weight (interference microscopy) of normal and hypertrophic heart muscle fibres. Nature, 1964, 202, 100-101.

8) Kompmann, M., Paddags, I. \& Sandritter, W. Feulgen cytophotometric DNA determinations on human hearts. Arch. Path., 1966, 82, 303-308.

9) Morishita, T., Sasaki, R. \& Yamagata, S. Studies on deoxyribonucleic content and cell count of human hearts. Jap. Heart $J ., 1970$, in press.

10) Sasaki, R., Morishita, T. \& Yamagata, S. A method for determining deoxyribonucleic acid synthetic time and mitotic time of heart muscle by autoradiographic technique. Tohoku J. exp. Med., 1970, 100, $15-21$. 


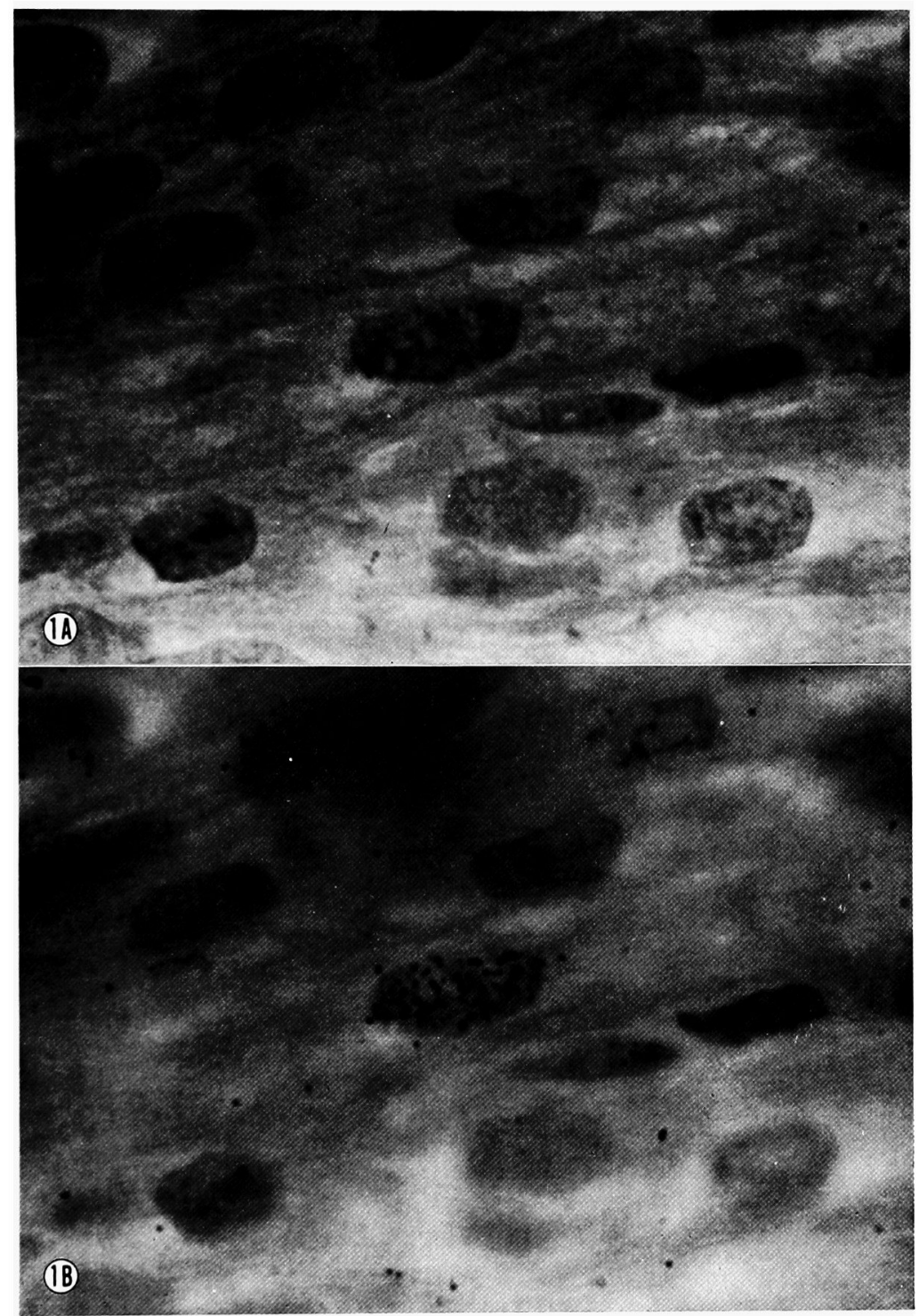

Fig. 1. Section of the myocardium of a 2-day-old rat showing the incorporation of ${ }^{3} \mathrm{H}$ thymidine into the heart muscle cell nucleus. 

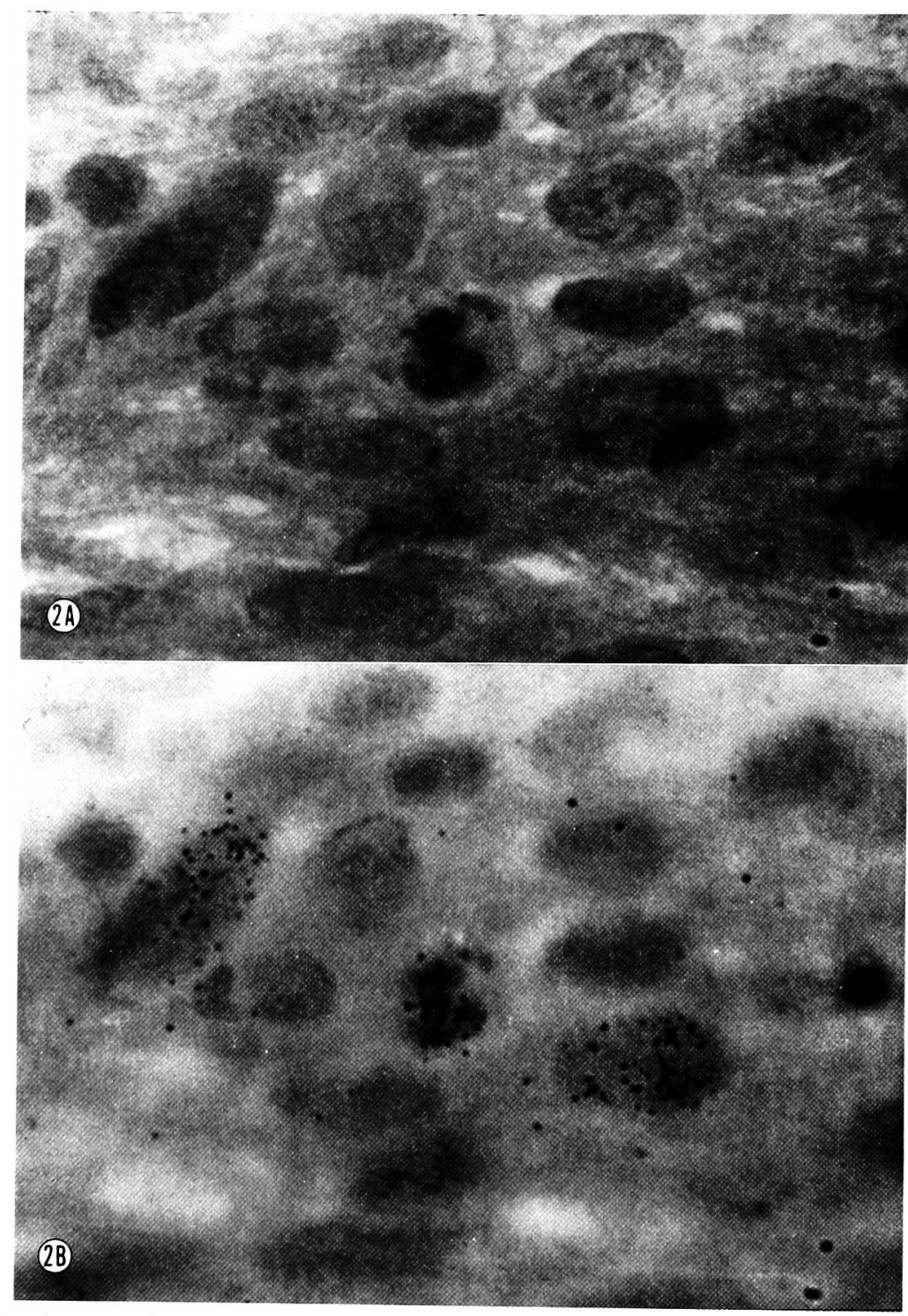

Fig. 2. Section of the myocardium of a 2-day-old rat showing heart muscle cell nucleus in mitotic state with concomitant ${ }^{3} \mathrm{H}$-thymidine incorporation. 


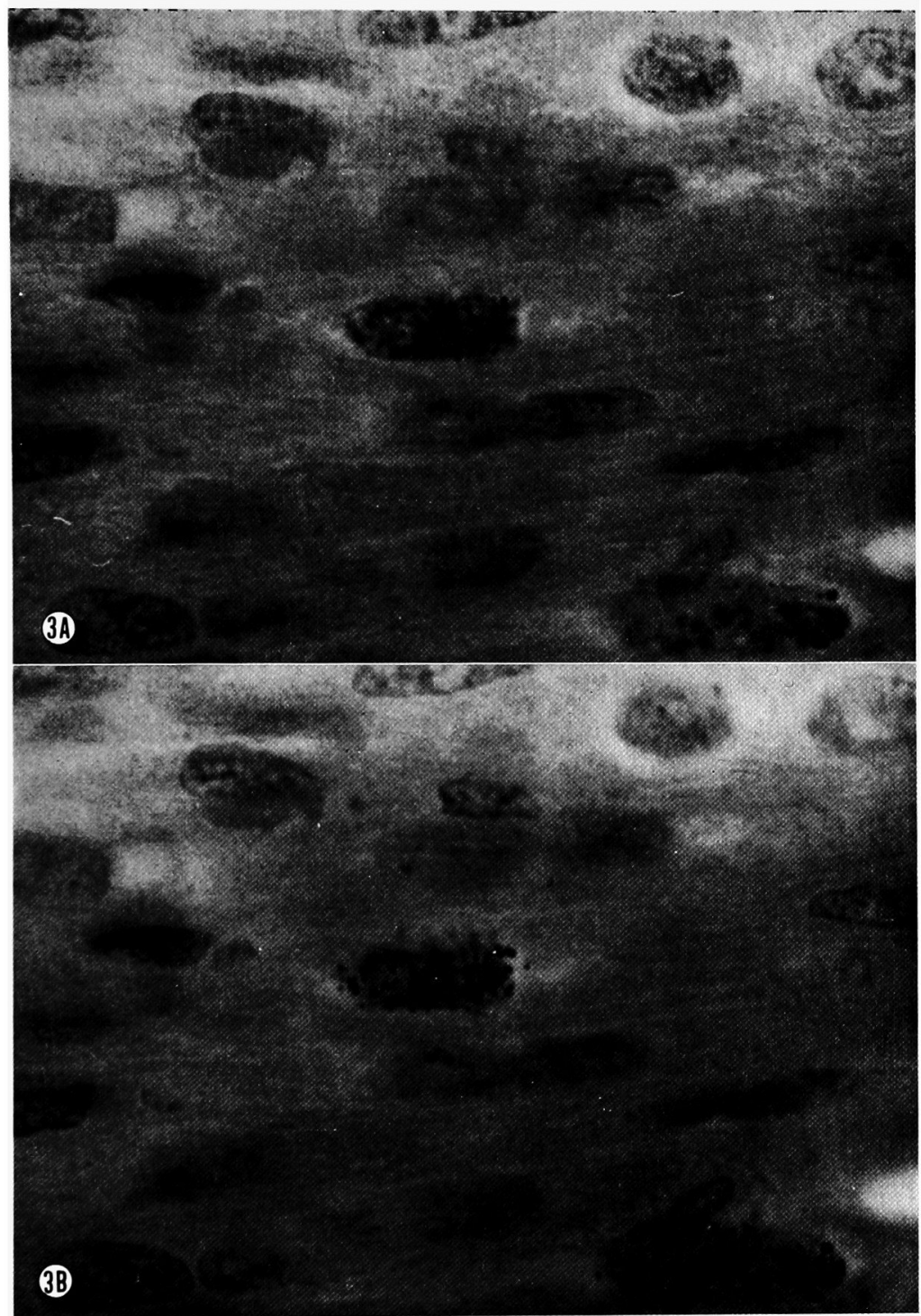

Fig. 3. Section of the myocardium of a 1 -week-old rat showing the incorporation of ${ }^{3} \mathrm{H}$ thymidine into heart muscle cell nucleus. 

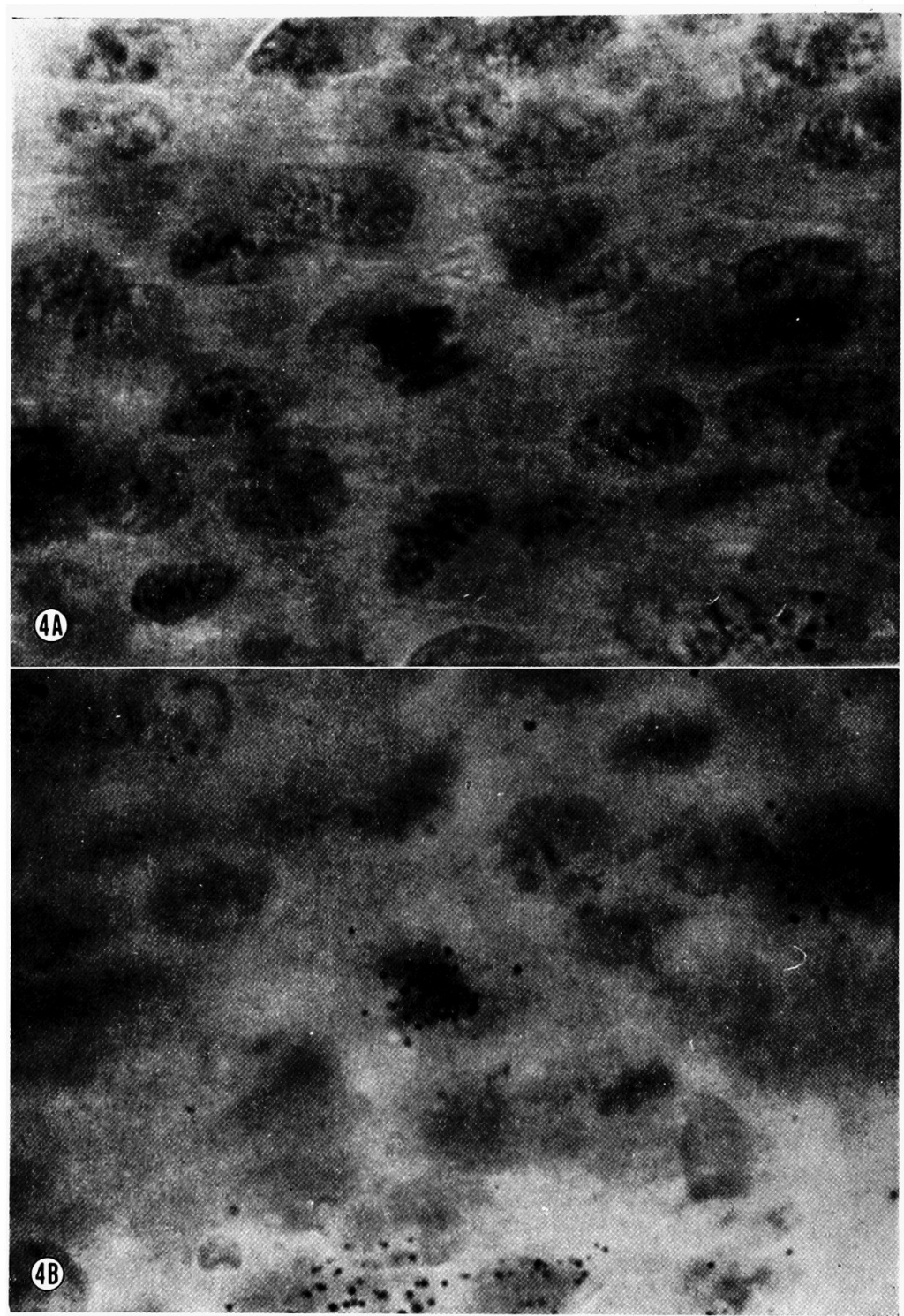

Fig. 4. Section of the myocardium of a l-week-old rat showing heart muscle cell nucleus in mitotic state with concomitant ${ }^{3} \mathrm{H}$-thymidine incorporation. 


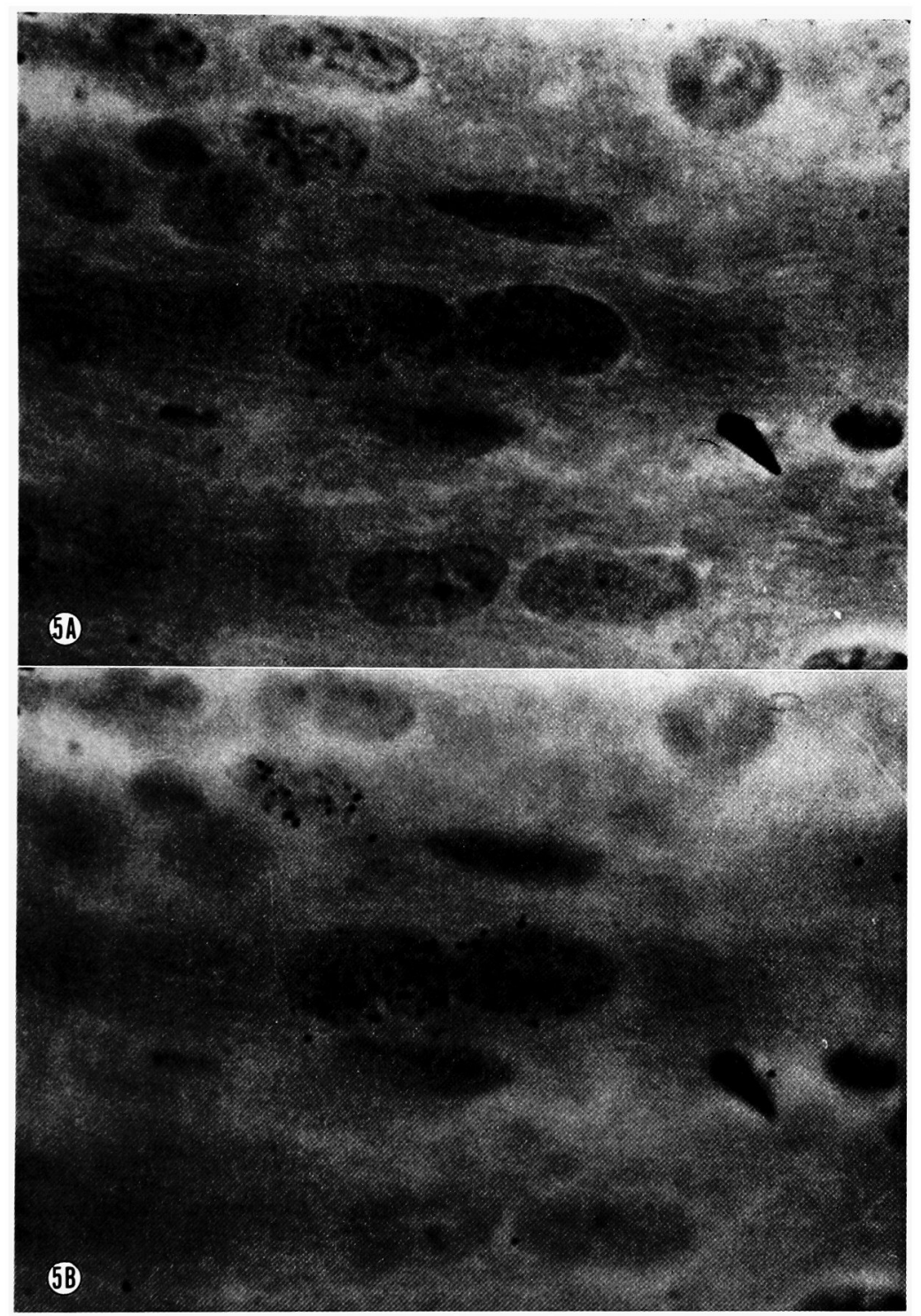

Fig. 5. Section of the myocardium of a 2 -week-old rat showing 2 adjacent heart muscle cell nuclei with ${ }^{3} \mathrm{H}$-thymidine incorporation. Though these nuclei appear to be ones soon after nuclear division, these are independent each other, since the incorporation and nuclear division cannot occur within 4 hours. 


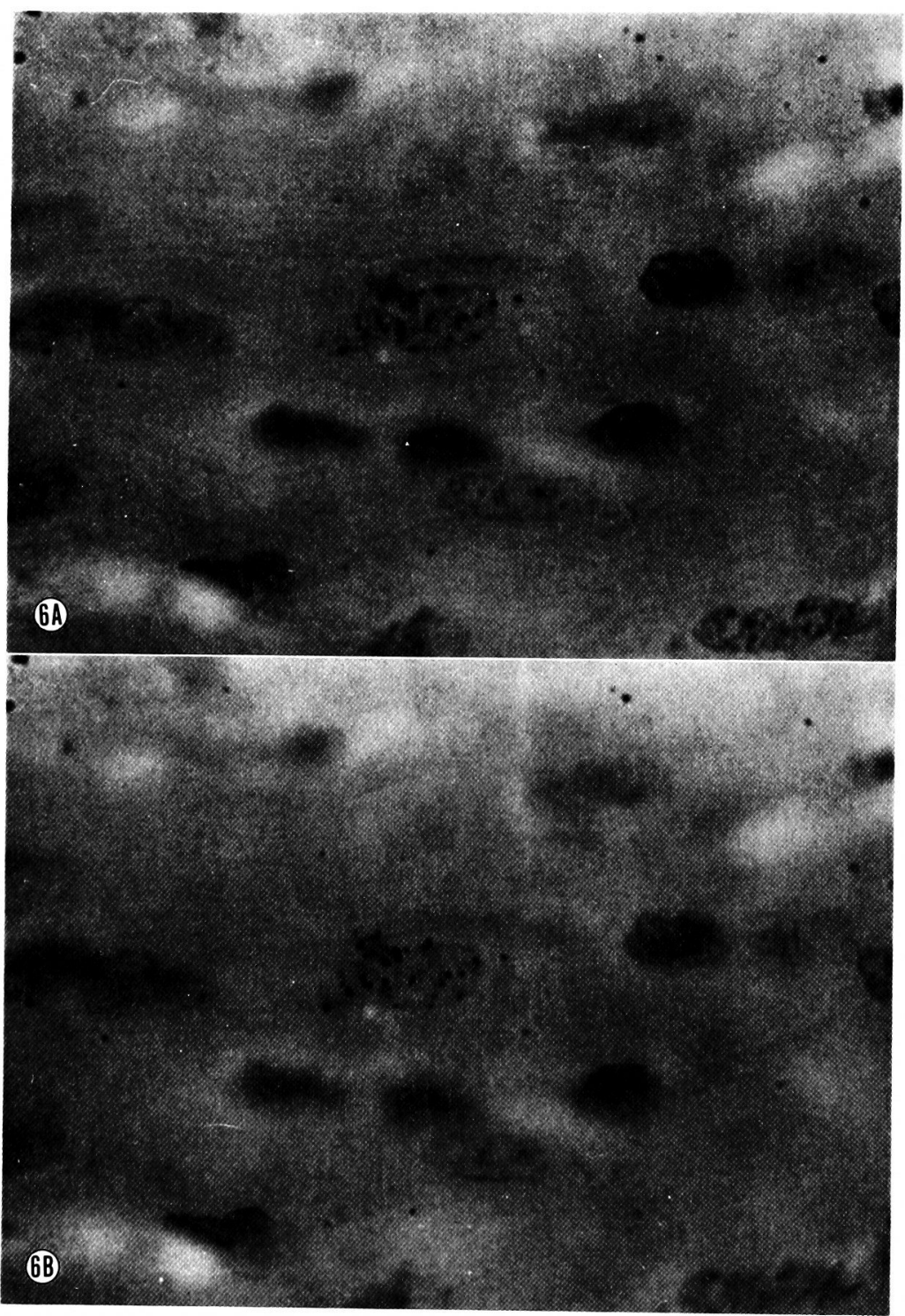

Fig. (6. Section of the myocardium of a 3 -week-old rat showing the incorporation of ${ }^{3} \mathrm{H}$ thymidine into heart muscle cell nucleus. 

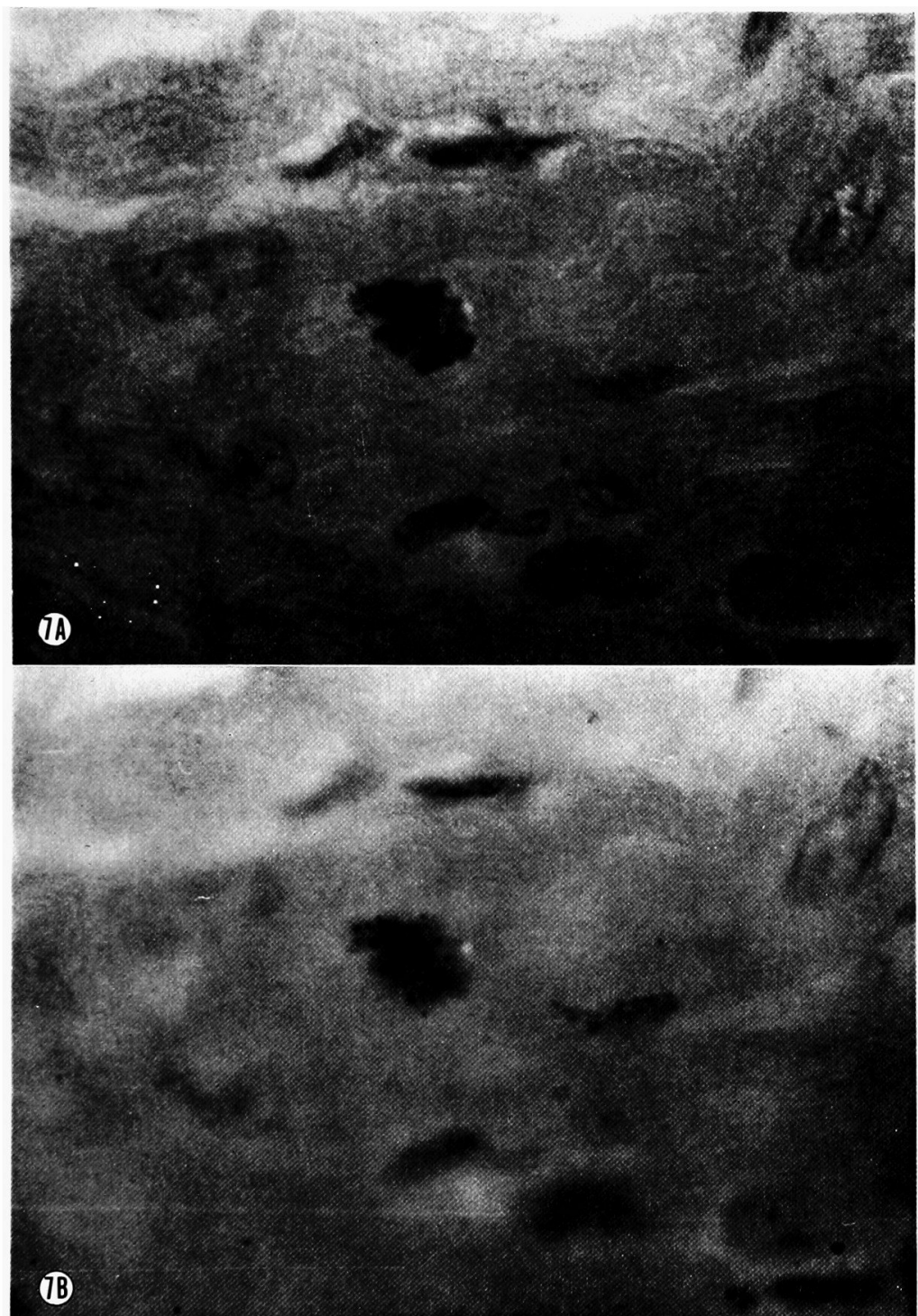

Fig. 7. Section of the myocardium of a 3 -week-old rat showing heart muscle cell nucleus in mitotic state with concomitant ${ }^{3} \mathrm{H}$-thymidine incorporation. 


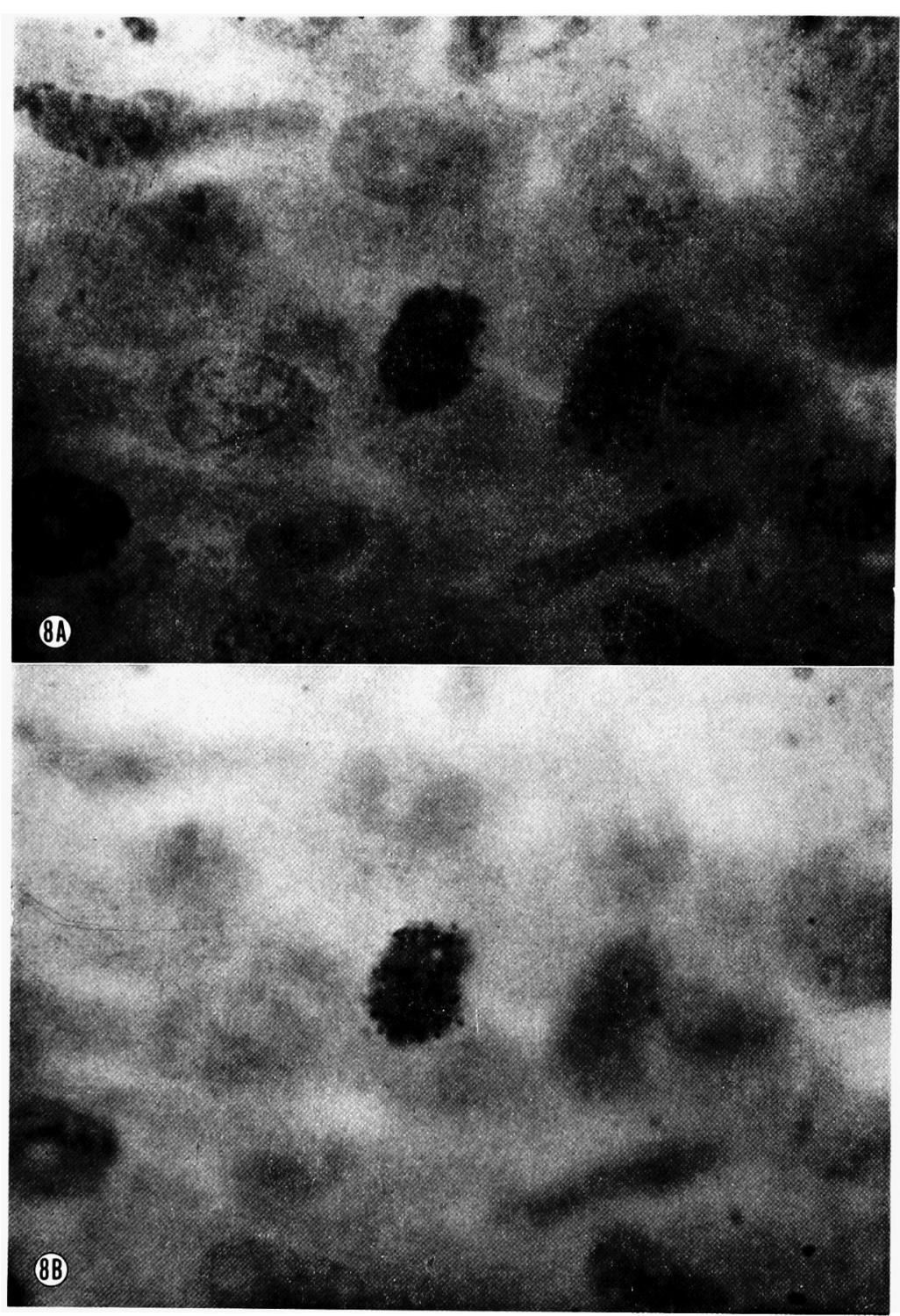

Fig. 8. Section of the myocardium of 2 -week-old rat showing interstitial cell nucleus in mitotic state with concomitant ${ }^{3} \mathrm{H}$-thymidine incorporation. 

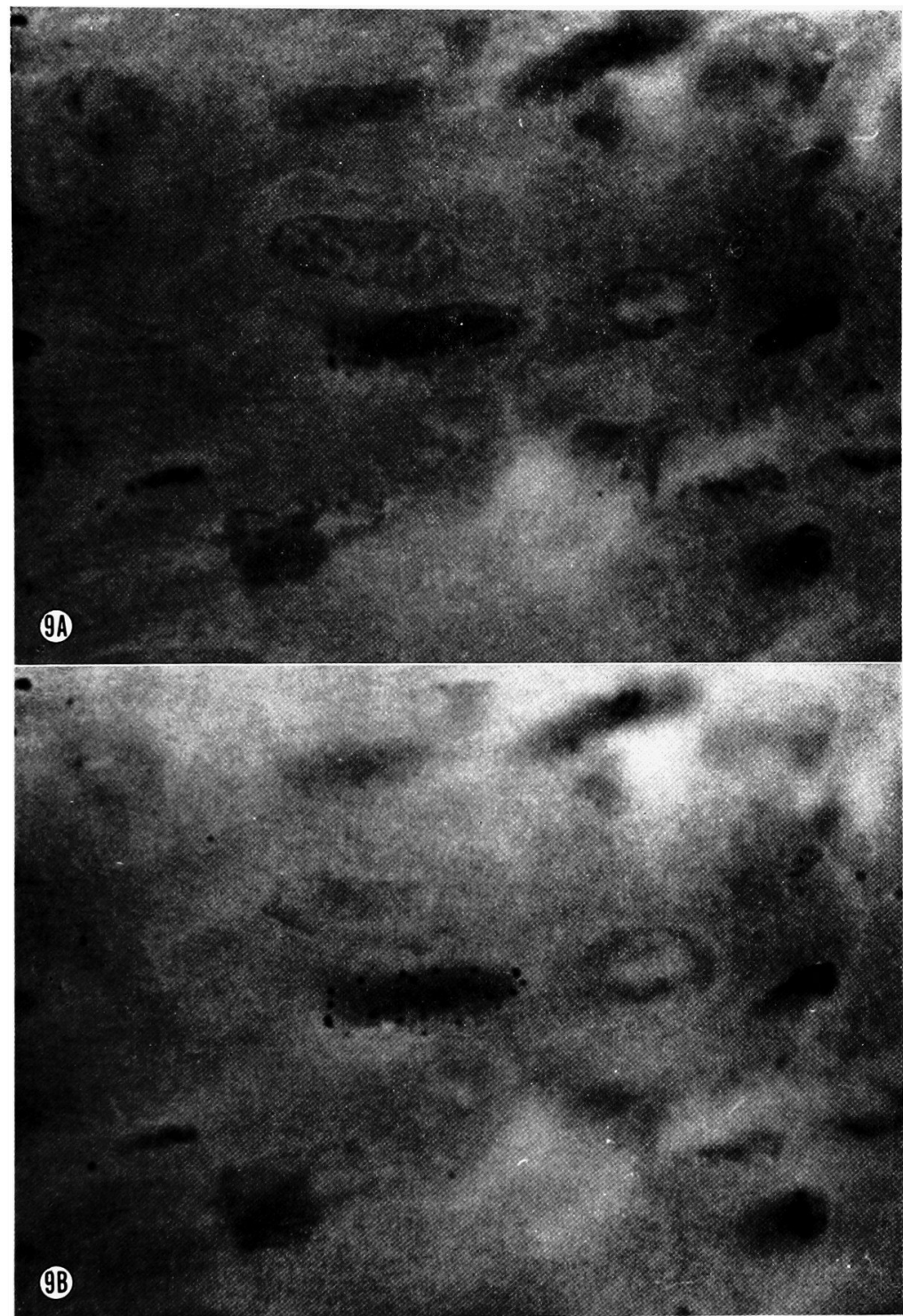

Fig. 9. Section of the myocardium of 3 -week-old rat showing the incorporation of ${ }^{3} \mathrm{H}$ thymidine into interstitial cell nucleus. 